\title{
Prospect of Judicial Preview in the Constitutional Court Based on the Construction of Constitutional Law
}

\author{
Diya Ul Akmal' ${ }^{1}$, Fatkhul Muin ${ }^{2}$, Pipih Ludia Karsa ${ }^{3}$ \\ Sultan Ageng Tirtayasa University, Banten, Indonesia \\ 10.15408/jch.v8i3.16940
}

\begin{abstract}
The Constitutional Court is a state institution that has the authority for reviewing laws against the Constitution (Judicial Review). Several times in issuing its decisions, the Constitutional Court has acted as a Positive Legislator. The potential for a legal vacuum as the implication of revoking a law is large. and also the slow formation of laws by the legislative body (DPR) and the lack of quality of regulations. The current law-making does not pay attention to legal ideals based on Pancasila so that the resulting legal products lose their meaning. This has resulted in many people whose constitutional rights have been violated. The state should be present to give full constitutional rights to its citizens. The Constitutional Court needs additional authority to maintain the supremacy of the constitution. additional authority as a preventive mechanism is Judicial Preview. The French state places Judicial Preview as an authority of the Constitutional Council. Austria and Germany apply Judicial Preview as a preventive measure for losses that can occur if the Draft Law is passed. A renewal of the Constitutional Law to perfect existing ones makes the prospect of Judicial Preview in Indonesia an Urgency for immediate implementation.

Keywords: Constitutional Court, Authority, Judicial Preview
\end{abstract}

* Received: October 27, 2020, revised: November 22, 2020, accepted: November 14, 2020, Published: December 5, 2020.

${ }^{1}$ Diya UI Akmal is a Researcher and Graduated from Sultan Ageng Tirtayasa University, Jl. Raya Jakarta KM. 04 Pakupatan, Serang, Banten. Email: diyaulakmal@gmail.com.

${ }^{2}$ Fatkhul Muin is a Lecturer at Sultan Ageng Tirtayasa University, Jl. Raya Jakarta KM. 04 Pakupatan, Serang. Email: fatkhulmuin@untirta.ac.id.

${ }^{3}$ Pipih Ludia Karsa is a Lecturer at Sultan Ageng Tirtayasa University, Jl. Raya Jakarta KM. 04 Pakupatan, Serang, Banten. Email: pipihludiakarsa@ymail.com.

*Corresponding Author: fatkhulmuin@untirta.ac.id. 


\title{
Prospek Pengujian Rancangan Undang-Undang di Mahkamah Konstitusi Berdasarkan Pembangunan Hukum Konstitusi
}

\begin{abstract}
Abstrak
Mahkamah Konstitusi merupakan lembaga negara yang memiliki kewenangan pengujian Undang-Undang terhadap Undang-Undang Dasar (Judicial Review). Dalam mengeluarkan putusannya Mahkamah Konstitusi beberapa kali bertindak sebagai Positif Legislator. Potensi terjadinya kekosongan hukum sebagai implikasi dicabutnya suatu Undang-Undang sangatlah besar. Ditambah dengan lambatnya pembentukan Undang-Undang oleh lembaga legislatif (DPR) serta kualitas peraturan yang kurang. Pembuatan Undang-Undang saat ini tidak memperhatikan cita hukum yang berakar pada Pancasila sehingga produk hukum yang dihasilkan kehilangan maknanya. Hal ini mengakibatkan banyak masyarakat yang dilanggar hak konstitusionalnya. Negara seharusnya hadir untuk memberikan hak konstitusional secara penuh kepada warga negaranya. Untuk mencegah hal tersebut maka Mahkamah Konstitusi membutuhkan suatu kewenangan tambahan untuk menjaga tegaknya supremasi konstitusi. Kewenangan tambahan sebagai mekanisme preventif tersebut berupa Pengujian Rancangan Undang-Undang (Judicial Preview). Perancis menempatkan Judicial Preview sebagai kewenangan dari Constitutional Council. Austria dan Jerman juga memberlakukannya sebagai tindakan pencegahan. Pembangunan Hukum Konstitusi untuk menyempurnakan yang sudah ada menjadikan prospek Pengujian Rancangan UndangUndang di Indonesia menjadi urgensi untuk segera diterapkan.

Kata Kunci: Mahkamah Konstitusi, Kewenangan, Judicial Preview
\end{abstract}

\section{Перспектива Судебного Надзора В Конституционном Суде На Основе Построения Конституционного Закона}

\begin{abstract}
Аннотация
Конституционный суд - это государственное учреждение, которое имеет право проверять законы на предмет соответствия Конституции. Вынося свои решения, Конституционный суд несколько раз выступал в качестве позитивного законодателя. Потенциал правового вакуума как последствия отмены закона огромен, особенно в сочетании с медленным формированием законов законодательным органом (DPR) и отсутствием качественных нормативных актов. Текущее формирование законодательства не обращает внимания на идеалы права, укоренившиеся в Pancasila, так что получаемые легальные продукты теряют свое значение. Это привело к тому, что конституционные права многих людей были нарушены. Государство должно присутствовать, чтобы предоставить своим гражданам полные конституционные права. Чтобы этого не произошло, Конституционному суду необходимы дополнительные полномочия для защиты верховенства конституции. Дополнительные полномочия в качестве превентивного механизма представлены в форме судебного предварительного надзора (Judicial Preview). Франция помещает судебный предварительный надзор в ведение Конституционного Совета. Австрия и Германия также приняли его в качестве меры предосторожности. Разработка Конституционного закона с целью усовершенствования существующего делает перспективу судебного надзора в Индонезии неотложной его реализацией.

Ключевые Слова: Конституционный Суд, Власть, Судебный Надзор
\end{abstract}




\section{A. INTRODUCTION}

The Constitutional Court was formed after the 3rd amendment contained in article $24 \mathrm{C}$ of the 1945 Constitution of the Republic of Indonesia. The authority of the constitutional court, include: a) Reviewing laws that are contrary to the Constitution; b) Determine disputes over the authority of state institutions whose powers are granted by this Constitution; c) Decide over the dissolution of political parties; d) Resolving disputes over the results of general elections, and e) Issue a decision on an application regarding the alleged violation by the President and/or Vice President as regulated in the Constitution. The Constitution has adjusted developments in the field of law in various other countries that have been guaranteed in the Constitution of these countries (Akbar, 2013: 179). With the establishment of the Constitutional Court, there is a significant influence on the pattern of relations between state institutions and the state tradition that has taken place. It is hoped that the constitution will be more complete and run consistently. It is more likely to 'tame' power by consistently enforcing the constitution (Hady, 2016: 147). Decisions of the Constitutional Court have legal consequences as a Judicial Decision in general. In reviewing laws against the Constitution, the form of the Constitutional Court Decision is a Declaratory Constitutional which means that the Constitutional Court's decision can create a new legal state or nullify a legal state. The Court acts as a Negative Legislator.

The Constitutional Court in exercising its authority several times issued decisions as a Positive Legislator. For example, the Constitutional Court issued Law on Cooperatives and Law on Irrigation to avoid a legal vacuum that could cause uncertainty and injustice. In its decision, The Constitutional Court stated that Law on Cooperatives contradicts the constitution, has no binding legal force, and re-enacted the old Law on Cooperatives for the time being until the formation of a new Law. And also Law on Water Resources which is declared contrary to the Constitution has no binding legal force and re-enacts the previous law. This is contrary to the provisions contained in Law on the Establishment of the Regulation Legislation and also the authority of the Constitutional Court as stated in the Constitution. Because the old Law on Cooperatives and old Law on Water Resources Development has been revoked by the parliament (DPR) following the decision of the Constitutional Court.

Indonesia must compare the authority of constitutional court institutions with other countries. The authority of the Constitutional Court which has been

given by the constitution must be expanded. Because the potential for legal vacuum is very large as an implication of the authority of the Constitutional 
Court in reviewing laws against the Constitution. The new Water Resources Law was passed by DPR at the Plenary Meeting on 17 September 2019 as an implementation of the Constitutional Court's decision, while the new Cooperative Law has not yet been formed. The legal vacuum that was filled by the old law happened for a long time. the slow pace of lawmaking by DPR has become a problem in the Indonesian legal system.

Upholding the supremacy of the constitution must be maintained as well as possible so as not to create violations of the rights of citizens committed by the government or the authorized institution. So additional authority is needed in the form of judicial preview which allows the Constitutional Court to oversee regulations before they are enacted. The Constitutional Court as The Guardian of the Constitution must be given the authority to oversee the constitution as a whole without waiting for any party to be harmed by the presence of a new law. The power of the government, in this case, the Executive, Legislative, and Judicial Power must be monitored so that it does not violate the constitution.

In this article, we will answer the main issues regarding the prospects of judicial preview in Indonesia. The issue will be elaborated into three parts starting from judicial review in the Constitutional Court, Comparative Judicial Review in Several Countries, and the prospect of adding judicial preview authority in Indonesian constitutional court.

\section{B. METHODS}

This research is a type of normative legal research that refers to the legal norms contained in the Legislation and Court Decisions as well as those in society and sees the hierarchical synchronization of a rule with other regulations. The approach used is comparative by comparing legal regulations and state institutions in other countries. The data used is secondary data and obtained through a literature study. The collected data will be analyzed qualitatively by interpreting and describing the data through words in the narrative with scientific logic.

\section{RESULTS AND DISCUSSION}

\section{Judicial Review in the Constitutional Court}

Amendments to the constitution brought changes to the Indonesian constitutional system. This change makes state institutions in Indonesia have the same position and there is no longer the highest state institution. This creates a 
better implementation of state power and perfects rules for governing a more democratic state. The formation of new state institutions was also accommodated as a form of demand for developing the needs of the nation. With the MPR no longer a high state institution, Indonesia has shifted from initially adopting a parliamentary supremacy system to constitutional supremacy so that state implementation is based on the constitution (Siahaan, 2010: 9-10). Three main characteristics mark the principle of constitutional supremacy, namely: a). The difference between constitutional legal norms and other legal norms; $b$ ). The authority is binding on the Constitution, and c). There is one institution that has the authority to review the constitutionality of laws and government legal actions.

Although this principle was born in another country, this principle can be universally recognized. In Indonesia, the Constitutional Court was present as a state institution to uphold the supremacy of the constitution. The Constitutional Court in Indonesia follows the model of the Constitutional Court in Austria. The Constitutional Court is an independent and separate institution from the Supreme Court (Siahaan, 2010: 11).

The main characteristic of the authority of the Constitutional Court is to review the law (Judicial Review). Judicial Review is defined as an authority granted to a judicial institution appointed by the constitution to conduct legal interpretations and constitutional interpretations to provide a judicial solution (Qamar, 2012: 2). Several reasons for reviewing the constitutionality of the law, namely (Ence, 2008: 7-8); a). The law is classified as a political product of two state institutions (the President and the DPR); b). The will of the people is reflected in the constitution; c). Many of the Laws that were made since "Orde Baru" are classified as authoritarian, repressive, and contrary to the constitution.

The authority of the Constitutional Court to reviewing laws against the Constitution, the review is carried out formally (formele toetsing), namely reviewing the legality of institutions, forms, and procedures or procedures for the formation of the Act and the review is carried out materially (materiele toetsinging), namely reviewing the consistency and suitability of the substance of the Law, whether an article, paragraph or section of the Act with the principles and spirit of the constitution (Siahaan, 2010: 11-12).

In reviewing laws against the Constitution, an application shall be submitted in writing in the Indonesian language by the applicant or his proxy to the Constitutional Court. For every application submitted, the Clerk of the Constitutional Court shall conduct a complete examination of the application. After the application has been registered, within 7 working days, a copy of the 
application is submitted to the DPR and the President. The applicant can withdraw the application before or during the court hearing. If the application is withdrawn, the Clerk of the Constitutional Court will issue the registration deed and notify the applicant. An application that has been withdrawn cannot be submitted again. The evidence presented must be legally accountable. The Constitutional Court determines whether or not the evidence is valid in a trial. If the decision of the Constitutional Court states that it is contrary to the constitution or does not fulfill the provisions of the formation of law, it is declared to have no binding legal force. The decision is published in the State Gazette after the decision is pronounced, no later than 30 (thirty) working days.

In implementing the authority to reviewing the Law against the constitution, there are problems, especially if an Act is revoked in its entirety. the repeal of the law and the slow pace of the creation of new laws by the DPR has the consequence of a legal vacuum. In some cases, the Constitutional Court acted as a Positive Legislator to avoid a legal vacuum, namely by re-enacting a law that had been repealed previously. As an example in the Constitutional Court Decision Number 85/PUU-XI/2013 which revoked Law on Water Resources and re-enacted Law on Irrigation. After the issuance of the Constitutional Court's ruling, it took a long time for the formation of a new law by the legislative body. It was only in September 2019 that the DPR passed a new Law on Water Resources. Even worse is related to the Law on Cooperatives that has been revoked by the Constitutional Court, which until now there has been no latest law that was passed.

\section{Comparative Judicial Review in Several Countries}

The Judicial Review was first carried out in the Madbury vs Madison case in 1803. The United States Supreme Court canceled the provisions in the Judiciary Act 1789 because it was considered contrary to the US Constitution. The United States Chief Justice, chaired by John Marshall, believes that this is a constitutional obligation of those who have been sworn to uphold the constitution even though there are no provisions in the US constitution nor a Law that gives Judicial Review authority to the Supreme Court (Konstitusi, 2010: 1-2). About legal developments in the United States, Beard stated that the Judicial Review was part of the system of checks and balances established in the Constitutional Convention.

Hans Kelsen put forward the idea of establishing a separate court outside the Supreme Court to handle the Review case when he was a member of the 
Chancellor in renewing the Austrian constitution in 1919-1920. The idea was accepted and became a part of the 1920 Austrian Constitution in which the Constitutional Court (Verfassungsgerichtshof) was formed. After world war II, the idea of a Constitutional Court with a Judicial Review spread throughout Europe by establishing a Constitutional Court separately from the Supreme Court. French adopted this concept differently by forming a Constitutional Council (Conseil Constitutional) and the former French colony followed. After the Soviet Union collapsed, the Communist countries reformed their country from an authoritarian state to liberal constitutional democracy (Siahaan, 2012: 4).

Until now, there are at least 80 countries around the world that have established the Constitutional Court. Based on the records by Jimly Asshiddiqie and Mustafa Fakhri until 2005, there were 78 countries that have the Constitutional Court, and after 2005 Arief Ainul Yaqin found at least 2 countries that also established the Constitutional Court namely the Republic of Kosovo which was officially established in December 2008 and the official Republic of Tajikistan was established in February 2016 (Yaqin, 2018: 1). There are several countries that are used as benchmarks in the formation of the Constitutional Court by other countries in the world. Among them Austria, Germany, and France which have a history of the formation and integration of authority into the Constitutional Court.

\section{a. Constitutional Court of Austria (Verfassungsgerichtshof)}

At the end of the 19th century, George Jelinek developed the idea of implementing Judicial Review applied in Austria (Asshiddiqie, 2016: 286). The idea of establishing the Austrian Constitutional Court was contained in the 1920 Constitution. The idea of establishing a Constitutional Court was given by Hans Kelsen when he was a member of the Chancellery in 1919-1920. Through the 1920 constitution, relations between countries were mapped. The Constitutional Court has the power to uphold Austrian constitutional values (Asshiddiqie and Syahrizal, 2006: 7).

The Constitutional Court is one of the three highest courts in Austria. This organ is domiciled in Vienna (the nation's capital). In the Austrian constitution, the Constitutional Court has several powers, including (Asshiddiqie and Syahrizal, 2006: 15):

a. Determine the constitutionality of Federal, state, and legality laws and regulations whose position is below the Act;

b. Having the authority to review international agreements in general; 
c. Resolving disputes on Presidential elections or Parliamentary Elections;

d. Deciding competency disputes between General Events and Administrative Courts or against all other types of justice; and

e. Decide on Impeachment of high state officials who are suspected of violating the law in carrying out their authority. The court only stated that the violation had been committed but the violation was considered minor so it was not accompanied by dismissal to the officials in question. The sanction that can be issued by the Court is the dismissal of a position holder from his position.

In reviewing the Law, the Constitutional Court may cancel the provisions of the Act in part or whole. One feature of the Austrian Constitutional Court is that it can delay the legal consequences of an annulment of more than 18 months. The legislature is allowed to correct mistakes as contained in the Act. The Austrian Constitutional Court still provides a margin of tolerance so as not to create a legal vacuum as a result of canceling a statutory regulation. Cancellation of a statutory regulation can also be accompanied by the enactment of a law that had previously been in force. But according to Herbert Hausmaniger, the court often avoided this application (Asshiddiqie and Syahrizal, 2006: 20-21).

\section{b. The Federal Constitutional Court (Bundesverfassungsgerict; abbreviated; BverfG)}

The German Federal Constitutional Court is based in Kalsruhe, which is dubbed the legal capital. that is because there are other high courts and the Federal Supreme Court. The German Constitutional Court consists of 16 judges who fill two panels. The first panel deals with issues related to fundamental rights and the second-panel deals with political issues (resolving constitutional disputes and examining the Act abstractly). Judge of the German Constitutional Court has a one-time term (12 years) (Asshiddiqie and Syahrizal, 2006: 44-47).

Article 93 Basic Law of 1949 regulates the authority of the German Federal Constitutional Court, including:

a. Constitutional Review, which is resolving disputes faced by high state institutions;

b. Judicial Review, namely reviewing concrete law norms or reviewing the law in general;

c. Constitutional Complaint, namely the right to submit petitions by 
individuals or groups because their constitutional rights have been violated by a legal product or a general court decision; and

d. Resolving disputes over the results of general elections (Article 41 II Basic Law).

In Constitutional disputes, the petitioner does not have to go through a general trial process as a concrete review. Government organs and legislators can directly apply to the German Federal Constitutional Court. A Draft Law which is considered problematic within 30 days of adoption by the Federal Parliament has already been submitted to the Constitutional Court. Review of Abstract Norms can be applied for by the Federal Government, State Governments, and the Federal Parliament. In the submission, the applicant only needs to put forward the argument that a loss can occur if the Act will later apply. In this Review, the judge can interpret broadly all articles and paragraphs contained in the Draft Law or the Act to be enacted. The potential loss becomes a material fact and acts as an essential factor that results in the decision (Asshiddiqie and Syahrizal, 2006: 49-53).

Concrete Review in the system at the German Federal Constitutional Court can be carried out after receiving the case submission from the general court. Concrete Review comes from the general court litigation process when the judge is uncertain about the application of a law or other legislation (Asshiddiqie and Syahrizal, 2006: 61). Constitutional Complaint can be done when all ordinary legal efforts in general court have been taken to recover the loss suffered by the applicant. Individual requests can be made by individuals or groups who postulate violations of the constitutional rights they experience to the Constitutional Court. These individual requests can be directed to the direct action of the state apparatus and also to the final decision of the Supreme Court that is alleged to violate the Basic Law principles (Asshiddiqie and Syahrizal, 2006: 71-72).

\section{c. The Constitutional Council (Conseil Constitutionel)}

A French scholar, Abb Sieys, proposed the establishment of a constitutional jury in 1793 . The existence of a constitutional jury can maintain the constitution. This can be done by canceling parliamentary legislation if deemed contrary to the constitution. Abb's opinion was far earlier than Hans Kelsen's in 1919.

The Constitutional Council was established in 1958 to coincide with the 
enactment of the constitution of the Fifth Republic of France. Initially, this organ was formed to disarm parliamentary power. The Constitutional Council is involved in determining the direction of state policy. This is because the Draft Law must first obtain approval from this organ. The Constitutional Council is an independent organ and is free from the influence of parliamentary power and its final decision and binding of other organs (Asshiddiqie and Syahrizal, 2006: 135136). This organ has the exclusive authority to conduct a constitutionality review of the Draft Law and the rules of procedure for the Parliament. A review of the Draft Law is considered to improve the quality of the draft legislation to be adopted by parliament.

There are 9 members of the French Constitutional Council determined by 3 state institutions, namely appointed by the president, chairman of the national assembly, and chairman of the senate. The term of office of members of the Constitutional council is nine years and cannot be re-elected after his term of office expires. Every three years there will be three new members who replace the three who stop. This is because one-third of the members quit every three years. To become a member of the constitutional council is only required to be over 18 years old. The composition of the constitutional council is carried out through political affiliation. So that board membership is dominated by professional politicians. In the period of president Giscard's leadership, he began to apply the terms of appointment which he called the neutral of appointment. The Constitutional Council has the responsibility of reviewing the harmony of the law with the constitution which includes the Organic Law (in general) and the permanent rules and regulations of the National Assembly and Senate. Besides, a review can also be carried out on international agreements made by the government. The authority to ratify or approve international treaties by the Constitutional Council applies from the amendment to the 1974 Constitution. The decision of the constitutional council is final and binding on all public power, administrative authority, and other public justice bodies (Asshiddiqie and Syahrizal, 2006: 151-154).

\section{Prospect of Judicial Preview in the Constitutional Court}

The essence of the constitution is the protection of human rights and their constitutional rights. Based on the hierarchy of statutory regulations, the rules below it must not conflict with the higher level. If the laws and regulations conflict, they can no longer be seen as a system that can be implemented and enforced (Kurniawan, 2014: 636-637). Constitutional Court decisions often provide justice in law enforcement. Many decisions are considered as legal 
breakthroughs in upholding the constitutionality of citizens. This has implications for the increase in requests for judicial review since it was first established. The recapitulation table for Judicial Review can be seen below:

Table 1.

Recapitulation of Law Case in the Constitutional Court from 2003 to 2019

\begin{tabular}{|c|c|c|c|}
\hline Year & $\begin{array}{c}\text { Application for } \\
\text { Judicial Review which } \\
\text { is Registered }\end{array}$ & $\begin{array}{c}\text { Number of Requests } \\
\text { Examined }\end{array}$ & $\begin{array}{c}\text { Number of } \\
\text { Decisions }\end{array}$ \\
\hline 2003 & 24 Applicant & 24 Case & 4 Case \\
\hline 2004 & 27 Applicant & 47 Case & 35 Case \\
\hline 2005 & 25 Applicant & 37 Case & 28 Case \\
\hline 2006 & 27 Applicant & 36 Case & 29 Case \\
\hline 2007 & 30 Applicant & 37 Case & 27 Case \\
\hline 2008 & 36 Applicant & 46 Case & 34 Case \\
\hline 2009 & 78 Applicant & 90 Case & 51 Case \\
\hline 2010 & 81 Applicant & 120 Case & 61 Case \\
\hline 2011 & 86 Applicant & 145 Case & 94 Case \\
\hline 2012 & 118 Applicant & 169 Case & 97 Case \\
\hline 2013 & 109 Applicant & 181 Case & 110 Case \\
\hline 2014 & 140 Applicant & 211 Case & 131 Case \\
\hline 2015 & 140 Applicant & 220 Case & 157 Case \\
\hline 2016 & 111 Applicant & 174 Case & 96 Case \\
\hline 2017 & 102 Applicant & 180 Case & 131 Case \\
\hline 2018 & 102 Applicant & 151 Case & 114 Case \\
\hline 2019 & 85 Applicant & 122 Case & 92 Case \\
\hline Total & 1321 Applicant & 1990 Case & 1291 Case \\
\hline
\end{tabular}

(Source: http://mkri.id/, accessed on April 1, 2020)

From the data above, it can be seen that there is an increase in applications registered at the Constitutional Court each year. In the last 4 years, it has seen a slight decrease but with a quantity of more than 100 registered cases. The Constitutional Court in 2019 must examine 37 cases that have not been resolved in 2018. It is undeniable that many legal products are still felt that are not in favor of the community. The law functions as a protection of human interests. In enforcing the law three elements must be considered, namely legal certainty (rechtssicherheit), expediency (zweckmassigkeit), and justice (gerechtigkeit) (Wijayanti, 2019: 186-187). Legal certainty is protection from the arbitrariness of authorized officials. In law enforcement, the community expects benefits for 
themselves personally, and subsequently, the order will be formed in the community. Law exists for humans, so its implementation must provide benefits and uses for humans. The law is present to provide justice, including a). The rule of law without discrimination; b). The realization of clean and professional institutions and legal apparatuses; c). The realization of gender justice; d). The realization of justice in the distribution of income, economic resources, and control of economic assets, and the loss of monopolistic practices.

The number of Judicial Reviews in the Constitutional Court on the material contained in the Law shows that the Law made by the DPR does not refer to the Constitution. The material content contained therein only uses Pancasila as a formality (Bo'a, 2018: 40-41). The ideals of Indonesian law are based on the Pancasila stated in the opening of the Constitution. The goal of the law is the necessity of directing the law to the ideals desired by the community as a regulatory and constructive measure. But in making the current law does not pay attention to the legal ideals so that the resulting legal products lose their meaning (Rahayu, 2015: 195). The number of laws reviewed can be seen below:

Table 2.

Number of Laws Reviewed from 2003 to 2019

\begin{tabular}{|c|c|}
\hline Year & Number of Laws Reviewed \\
\hline 2003 & 16 \\
\hline 2004 & 14 \\
\hline 2005 & 12 \\
\hline 2006 & 9 \\
\hline 2007 & 12 \\
\hline 2008 & 18 \\
\hline 2009 & 27 \\
\hline 2010 & 58 \\
\hline 2011 & 55 \\
\hline 2012 & 0 \\
\hline 2013 & 64 \\
\hline 2014 & 71 \\
\hline 2015 & 77 \\
\hline 2016 & 72 \\
\hline 2017 & 58 \\
\hline 2018 & 45 \\
\hline 2019 & 51 \\
\hline Total & $\mathbf{6 5 9}$ \\
\hline & \\
\hline
\end{tabular}


Hundreds of Laws have been reviewed since it was first formed. A large number of judicial reviews is seen as a lack of legislative results made by the $D P R$ and does not meet public expectations. This set a bad precedent when the age of the country entering 74 years stood. The law must be present for the benefit not for curbing the constitutional rights of its citizens. Several things cause many problematic legal products, namely (Maulana, 2018: 786-787):

a. In the practice of politics many interests wish to be forced into the law;

b. There are limitations to interpreting the constitution into lower regulations; and

c. The DPR still has not seen substantive matters and has not yet looked forward to the benefit of the community.

There are two authorities in the relationship between the legislators and the judicial review, both as legislative functions but with different roles. Laica Marzuki argued, "when the Constitutional Court is a Negative Legislator, the parliament that makes the Act is called Positive Legislator" (Utomo, 2015: 827). The Constitutional Court several times issued a ruling as a Positive Legislator. Decisions of the Constitutional Court often formulate new policies to protect the rights of citizens (Bisariyadi, 2015: 483). Sometimes the implication of the Constitutional Court as a Positive Legislator is the absence of a legal vacuum. even in the Constitutional Court Decision Number 28/PUU-XI/2013 and the Constitutional Court Decision Number 85/PUU-XI/2013 re-enacting the Law that was previously revoked. On one hand, the Constitutional Court carries out its duties as the enforcer of the supremacy of the constitution but on the other hand, the Constitutional Court has overtaken the authority granted by the constitution. This further adds to the question of the legislative process undertaken. An Act ratified as a substitute for a Law that is declared unconstitutional must be revoked for the same reason.

Following the principles of constitutional supremacy and rule of law, constitutional judges must submit to the constitution. The Constitutional Court is not above the constitution but also should not be too limited in its interpretation because this authority is a suggestion to realize the living constitution (Safaat, Widiarto, and Suroso, 2017: 237). In addition to maintaining true constitutional sovereignty, there are deficiencies in the implementation of judicial review in Indonesia. Judging from the comparison with other countries, there are significant differences in the application of constitutional review. 
Constitutional review is divided into two, namely (Yaqin, 2018: 41):

a. Abstract Review can be divided into 2, namely:

1) Reviewing the Draft Law that has been approved by Parliament but has not yet been approved and enacted (A Priori Review); and

2) Reviewing Laws that have been passed and enacted (A Posteriori Review).

b. Concrete Review, namely reviewing the Law in concreto conditions (the Act is in the process of being applied in court).

In Indonesia, there is no concrete norm review and there is only abstract norm review which is only limited to the review of a law that has been passed (A Posteriori Review). Judicial review has the unavoidable possibility when a person has the possibility of suffering constitutional losses as a result of the implementation of a law. Besides, the judicial review does not examine synchronization between laws or the accuracy of the implementation of legal concepts in the law (Nalle, 2013: 440). And the consequences that can arise from the Constitutional Court Decision is the existence of a legal vacuum. Because the law cannot be formed in a short time. A new authority is needed to be given to the Constitutional Court to refer to the application of judicial review in other countries. At present in the Constitution and Law concerning the Constitutional Court, there is no knowledge of the authority to review the Draft Law. Policymakers must have the foresight to address the legal problems that exist in Indonesia.

The concept of Reviewing the Draft Law as a preventive mechanism can be carried out in Indonesia. It can be applied to several problems, include:

a. It can be applied as a mechanism for making laws. Before it is ratified by the $D P R$, it must first be reviewed by the Constitutional Court. This can minimize the possibility of constitutional violations experienced by citizens;

b. The mechanism for reviewing the draft law can also be carried out before an international agreement is ratified by the DPR. As Noor Sidharta argues (Savitri, 2019: 62-63), "The Indonesian Constitutional Court can conduct a legal review of the ratification of international treaties by adding the authority to the Constitution and administratively that is at the request of the DPR";

c. Reviewing the Draft Law can be a mechanism for no more regulations that conflict with higher regulations. Because Indonesia implementing a two- 
roof review, so if there are laws that contradict the constitution in the Judicial Review it will affect all the regulations that are under the Act;

d. As a protection mechanism so that DPR and the President do not contain legal norms that have been canceled by the Constitutional Court. Noncompliance with the decisions will institutionally damage the authority and dignity of the Constitutional Court and the absence of legal certainty. Regulations made must answer the needs of the community. So when society changes, the law must follow it (Abadi and Hajri, 2017: 134); and

e. Minimizing the possibility of legal vacuum as the implication of the Constitutional Court's decision. This is one of the most important and felt as urgent in giving authority to reviewing the draft law to the Constitutional Court to maintain order in the life of the state and society.

To add the authority to review the draft law can be done in several ways, including:

a. amendments to the constitution; This will provide strong legal certainty because the Constitutional Court is a state institution formed by the Constitution. However, this mechanism will take a long time because it is uncertain when the amendment will be made. And when amending cannot be done just one article but covers the entire contents of the article which is problematic or wants to be changed;

b. Revise the law concerning the constitutional Court; Revising the Law can be done faster than having to wait for amendments to the Constitution. However, this revision can only be done by the legislative body which in this case is the DPR;

c. Revise the Law concerning the Establishment of Legislation and/or Law concerning MD3; Frequently the DPR makes revisions to the law concerning MD3, it can be used to add the authority of the Judicial Preview to the Constitutional Court. This is done to legitimize when the DPR submits/requests to be reviewing the constitutionality of the Draft Law to the Constitutional Court; and

d. Through the Jurisprudence of Constitutional Justices; this method is the simplest compared to Amending the Basic Law or revising the Law. But this can only be done if there is an applicant who submits the Draft Law to the Constitutional Court. 


\section{CONCLUSIONS}

The authority of the Constitutional Court in conducting a Judicial Review upholds the supremacy of law and the constitution in Indonesia. The ruling of the Constitutional Court has implications for the legal vacuum. This is as a result of the slow process of legislation in forming laws. the slow formation of the law does not correlate with the good quality of the law. The authority of the Judicial Review held by the Constitutional Court is not enough to protect the constitutional rights of citizens. The prospect of reviewing the draft law in Indonesia is felt to be an urgency to oversee the formation of the Act to be following the 1945 Constitution of the Republic of Indonesia. This authority is expected to minimize the possibility of constitutional violations obtained from the presence of law. And to minimize the potential for legal vacuum as a result of the repeal of a law.

In the prospect of the implementation mechanism, some things can be done, namely: First, by applying to reviewing the Draft Law by the senate (DPD) in the legislative chamber. this request is at the same time strengthening the authority of the DPD so that later the DPD can balance the authority of the DPR in the issue of the quality of authority. Second, the Constitutional Court is given the authority to be able to review the Draft Law without being petitioned if deemed urgent. And third, those who submit applications are the community as individuals or indigenous groups. This is to accommodate the full sovereignty of the people in the Indonesian constitutional system.

\section{REFERENCES:}

\section{Books}

Abadi, M. H., \& Hajri, W. A. Pemuatan Norma Hukum yang Telah Dibatalkan oleh Mahkamah Konstitusi. Yogyakarta: DEEPUBLISH, 2017.

Akbar, P. Lembaga-lembaga Negara Menurut UUD NRI Tahun 1945. Jakarta: Sinar Grafika, 2013.

Asshiddiqie, J. Konstitusi Bernegara Praksis Kenegaraan Bermartabat dan Demokratis. Malang: Setara Press, 2016.

Asshiddiqie, J., \& Syahrizal, A. Peradilan Konstitusi di 10 Negara. Jakarta: Konstitusi Press, 2006.

Ence, I. A. Negara Hukum \& Hak Uji Konstitusionalitas Mahkamah Konstitusi (Telaah Terhadap Kewenangan Mahkamah Konstitusi). Bandung: PT. Alumni, 2008. 
Hady, N. Teori Konstitusi dan Negara Demokrasi (Paham Konstitusionalisme Demokrasi di Indonesia Pasca Amandemen UUD 1945). Malang: Setara Press, 2016.

Siahaan, M. Hukum Acara Mahkamah Konstitusi Republik Indonesia. Jakarta: Sinar Grafika, 2012.

Tim Penyusun Hukum Acara Mahkamah Konstitusi. Hukum Acara Mahkamah Konstitusi. Jakarta: Sekretariat Jenderal dan Kepaniteraan Mahkamah Konstitusi, 2010.

Yaqin, A. A. Constitutional Question Kewenangan Yang Terlupakan Dan Gagasan Untuk Melembagakannya Di Mahkamah Konstitusi. Jakarta: Sinar Grafika, 2018.

\section{Articles}

Bisariyadi. Yudisialisasi Politik dan Sikap Menahan Diri: Peran Mahkamah Konstitusi Dalam Menguji Undang-Undang, Jurnal Konstitusi, Volume 12 Number 3 (2015). https://doi.org/10.31078/jk1233

Bo'a, F. Y. Pancasila Sebagai Sumber Hukum Dalam Sistem Hukum Nasional, Jurnal Konstitusi, Volume $15 \quad$ Number 1 (2018). https://doi.org/10.31078/jk1512

Kurniawan, A. K. Judicial Preview Sebagai Mekanisme Verifikasi Konstitusionalitas Suatu Rancangan Undang-Undang, Jurnal Konstitusi, Volume 11 Number 4 (2014).

Maulana, M. R. Upaya Menciptakan Produk Hukum Berkualitas Konstitusi Melalui Model Preventif Review, Jurnal Konstitusi, Volume 15 Number 4, (2018). https://doi.org/10.31078/jk1545

Nalle, V. I. Konstruksi Model Pengujian Ex Ante terhadap Rancangan UndangUndang di Indonesia, Jurnal Konstitusi, Volume 10 Number 3 (2013).

Qamar, N. Kewenangan Judicial Review Mahkamah Konstitusi, Jurnal Konstitusi, Volume I Number 1 (2012).

Rahayu, D. P. Aktualisasi Pancasila Sebagai Landasan Politik Hukum Indonesia, Yustisia, Volume 4 Number 1 (2015). https://doi.org/10.20961/yustisia.v4i1

Safaat, M. A., Widiarto, A. E., \& Suroso, F. L. Pola Penafsiran Konstitusi dalam Putusan Mahkamah Konstitusi Periode 2003 - 2008 dan 2009 - 2013, Jurnal Konstitusi, Volume 14 Number 2 (2017). https://doi.org/10.31078/jk1421 
Savitri, D. N. Constitutional Preview, and Review of International Treaties: France and Indonesia Compared, Constitutional Review, Volume 5 Number 1 (2019). https://doi.org/10.31078/consrev512

Siahaan, M. Uji Konstitusionalitas Peraturan Perundang-Undangan Negara Kita: Masalah dan Tantangan, Jurnal Konstitusi, Volume 7 Number 4 (2010).

Utomo, N. A. Dinamika Hubungan Antara Pengujian Undang-Undang dengan Pembentukan Undang-Undang, Jurnal Konstitusi, Volume 12 Number 4 (2015). https://doi.org/10.31078/jk1248

Wijayanti, W. Eksistensi Undang-Undang Sebagai Produk Hukum Dalam Pemenuhan Keadilan Bagi Rakyat (Analisis Putusan Mahkamah Konstitusi Nomor 50/PUU-X/2012), Jurnal Konstitusi, Volume 10 Number 1 (2012).

\section{Legal Instrument}

1945 Constitution of the Republic of Indonesia

Constitutional Court Decision Number 28/PUU-XI/2013

Constitutional Court Decision Number 85/PUU-XI/2013

Law Number 8 of 2011 concerning Amendments to Law Number 24 of 2003 concerning the Constitutional Court

\section{Internet}

Mahkamah Konstitusi, "Rekapitulasi Perkara Pengujian Undang-Undang", https://mkri.id/index.php?page=web.RekapPUU, accessed on April 1, 2020. 